\title{
Bordetella hinzii Pneumonia and Bacteremia in a Patient with SARS-CoV-2 Infection
}

\author{
Michele Maison-Fomotar, Geetha Sivasubramanian
}

Patients with severe acute respiratory syndrome coronavirus 2 infection may have bacterial co-infections, including pneumonia and bacteremia. Bordetella hinzii infections are rare, may be associated with exposure to poultry, and have been reported mostly among immunocompromised patients. We describe $B$. hinzii pneumonia and bacteremia in a severe acute respiratory syndrome coronavirus 2 patient.

Since the December 2019 beginning of the coroOnavirus disease (COVID-19) pandemic, caused by severe acute respiratory syndrome coronavirus (SARS-CoV-2), there have been >180 million cases and $>3.9$ million deaths worldwide (1). Severe bacterial and fungal co-infections are a major concern with COVID-19 and increase disease mortality (2).

The genus Bordetella comprises $>10$ known species of small, gram-negative coccobacilli, the most common of which is Bordetella pertussis (3). Bordetella hinzii was first identified as a cause of respiratory infection in poultry and more rarely in rodents (4). It was first reported as a human infection in a patient with HIV infection in 1994 as a cause of bacteremia (5) and has subsequently been identified as a cause of soft tissue infections, pneumonia, cholangitis, urinary tract infections, bacteremia, and endocarditis, most often in immunocompromised patients (4-15; Appendix references 16,17, https://wwwnc.cdc.gov/EID/ article/27/11/21-1468-App1.pdf). We report a case of $B$. hinzii pneumonia and bacteremia in a patient with SARS-CoV-2 infection.

\section{The Study}

A 77-year-old man with medical history notable for uncontrolled type 1 diabetes mellitus and coronary artery disease and who was receiving hemodialysis for

Author affiliation: University of California, San Francisco, Fresno, California, USA

DOI: https://doi.org/10.3201/eid2711.211468 end-stage renal disease sought treatment with worsening shortness of breath and 3 days of chest pain. He also reported cough, nausea, fever, and back pain. He lived at a nursing home and had no known poultry or pet exposure. At initial examination, he was afebrile; had a blood pressure of 165/83 $\mathrm{mm} \mathrm{Hg}$; heart rate of 92 beats/min, and respiratory rate of 18 breaths/min; was severely hypoxic with oxygen saturation of $50 \%$ on room air, requiring a nonrebreather mask; and had decreased breath sounds on chest auscultation. Blood test results (reference ranges) showed hemoglobin, $10 \mathrm{~g} / \mathrm{dL}(12-16 \mathrm{~g} / \mathrm{dL})$; leukocytes, 4,300 cells $/ \mathrm{mm}^{3}$ $\left(4,000-11,000\right.$ cells $\left./ \mathrm{mm}^{3}\right), 78 \%$ neutrophils; platelets, $238,000 / \mathrm{mm}^{3}\left(140,000-440,000 / \mathrm{mm}^{3}\right)$; serum creatinine level, $4.3 \mathrm{mg} / \mathrm{dL}(0.5-1.1 \mathrm{mg} / \mathrm{dL})$; procalcitonin, $3.3 \mathrm{ng} / \mathrm{mL}(0.00-0.30 \mathrm{ng} / \mathrm{mL})$; lactate dehydrogenase, $169 \mathrm{U} / \mathrm{L}$ (100-230 U/L); C-reactive protein, $213 \mathrm{mg} / \mathrm{L}$ (0.0-3.0 mg/L); and ferritin, 2,492 ng/mL (22.0-322.0 $\mathrm{ng} / \mathrm{mL}$ ). A SARS-CoV-2 nasopharyngeal swab sample test was positive by PCR. A computed tomography scan of his chest revealed multiple rib fractures, a large right-side pleural effusion, and right upper-lobe pulmonary infiltrate.

We started the patient on dexamethasone. We considered remdesivir therapy but did not start it because of his renal disease. We also empirically initiated treatment with piperacillin/tazobactam and levofloxacin for bacterial pneumonia. We performed right-side thoracentesis and drained $725 \mathrm{~mL}$ of transudative fluid; fluid culture was negative for growth of bacteria. He was intubated on day 7 after admission because of worsening hypoxemia but subsequently extubated on day 9 . On day 13 , acute respiratory failure (oxygen saturation $\approx 70 \%$ ) and bradycardia (heart rate $\approx 40$ beats/min) developed, and he was hypotensive with agonal breathing. He was emergently reintubated and given atropine, which improved his heart rate. We initiated broad-spectrum antimicrobial treatment with intravenous vancomycin and cefepime. 
Blood cultures drawn on day 13 after admission grew gram-negative rods in routine blood, chocolate, and MacConkey agar media. A computed tomography scan of the chest revealed bilateral patchy ground glass opacities, dense consolidations in both lung bases, and a small right pleural effusion (Figure). The patient underwent a bronchoalveolar lavage (BAL) on day 14; the BAL fluid grew $>100,000$ CFUs of the same gram-negative bacilli, which we had not yet identified, along with 20,000-50,000 CFUs of Klebsiella pneumoniae. Gram stain of the BAL fluid showed many leukocytes and few gram-negative rods. We continued treatment with vancomycin and cefepime. On day 17, we extubated then reintubated him the same day because of ongoing hypotension and poor mentation. Because of worsening hemodynamic status, continued poor mentation, and overall poor prognosis, we changed goals of care to comfort measures only, and the patient died soon after.

On day 18 after the patient's admission, we identified the gram-negative rod in the blood culture and BAL fluid as Bordetella hinzii on the basis of an excellent score (2.43) in matrix-assisted laser desorption/ionization-time of flight mass spectrometry testing. We measured antimicrobial sensitivities by broth microdilution using the Vitek 2 system (bioMérieux; https://www.biomerieux.com) and MIC, interpreting breakpoints using Clinical and Laboratory Standards Institute (https://clsi.org) guidelines. The isolate was sensitive only to meropenem, levofloxacin, amikacin, and gentamicin and showed high MICs of $32 \mu \mathrm{g} / \mathrm{mL}$ to ceftazidime and $64 \mu \mathrm{g} / \mathrm{mL}$ to cefepime (Table 1).

\section{Conclusions}

$B$. hinzii is a strictly aerobic gram-negative bacillus that was first identified as a cause of respiratory illnesses, mostly rhinotracheitis, in poultry (3). Manifestations from reported human cases include skin infection, urinary tract infection, pneumonia, and infective endocarditis, with or without bacteremia (4-15; Appendix references 16,17) (Table 2). Human infection with $B$. hinzii is very uncommon; the 18 cases thus far reported suggest that $B$. hinzii behaves like an opportunistic pathogen in humans. Underlying conditions in patients from those cases included HIV, malignancy, liver disease, ulcerative colitis, diabetes, and liver transplantation; 3 of the patients had no underlying medical conditions. There was often known poultry exposure, unlike in this case. It is possible that this pathogen colonizes the respiratory tract then is activated to cause infection later when the host becomes immunocompromised (7;

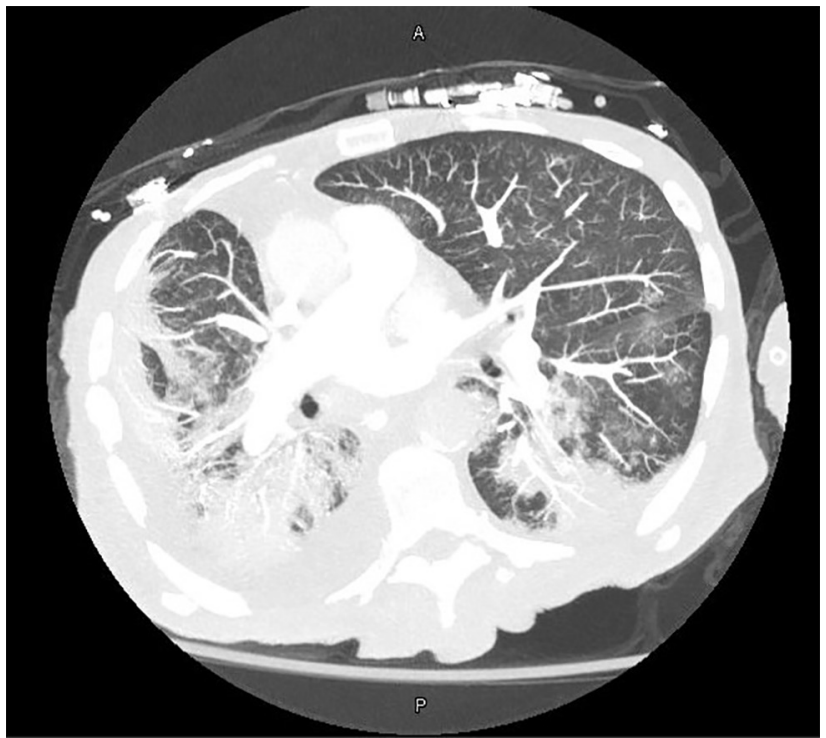

Figure. Computed tomography image of the chest showing bilateral dense consolidations and right-sided pleural effusion in 77-year-old man with severe acute respiratory syndrome coronavirus 2 who was later found to be co-infected with Bordetella hinzii. A, anterior; $\mathrm{P}$, posterior

Appendix reference 16). B. hinzii was isolated from wild rodents in Southeast Asia, raising the possibility that they might serve as reservoirs that could transmit the pathogen to humans or pets (Appendix reference 18). Most patients recovered when treated with appropriate antimicrobial drugs, but this infection can lead to death, especially in severely immunocompromised patients $(10,13)$.

$B$. hinzii is frequently resistant to many antimicrobial drugs, including $\beta$-lactams, cephalosporins, and quinolones. Reported isolates have been susceptible to piperacillin/tazobactam, ceftazidime, tigecycline, and meropenem (4-11). The interpretation of antimicrobial sensitivity testing is not established. Choice of antimicrobial drugs and treatment duration are also not standardized. The cases of bacteremia and endocarditis identified were treated with

\begin{tabular}{|c|c|c|}
\hline Drug & $\mathrm{MIC}^{*}$ & Interpretation \\
\hline Amikacin & $8 \mu \mathrm{g} / \mathrm{mL}$ & Sensitive \\
\hline Aztreonam & $\geq 64 \mu \mathrm{g} / \mathrm{mL}$ & Resistant \\
\hline Cefepime & $\geq 64 \mu \mathrm{g} / \mathrm{mL}$ & Resistant \\
\hline Ceftazidime & $\geq 32 \mu \mathrm{g} / \mathrm{mL}$ & Resistant \\
\hline Ciprofloxacin & $\geq 8 \mu \mathrm{g} / \mathrm{ml}$ & Resistant \\
\hline Gentamicin & $4 \mu \mathrm{g} / \mathrm{mL}$ & Sensitive \\
\hline Levofloxacin & $2 \mu \mathrm{g} / \mathrm{mL}$ & Sensitive \\
\hline Meropenem & $2 \mu \mathrm{g} / \mathrm{mL}$ & Sensitive \\
\hline Piperacillin/tazobactam & $\geq 128 / 4 \mu \mathrm{g} / \mathrm{mL}$ & Resistant \\
\hline Ticarcillin/clavulanic acid & $\geq 256 / 2 \mu \mathrm{g} / \mathrm{mL}$ & Resistant \\
\hline Tobramycin & $16 \mu \mathrm{g} / \mathrm{mL}$ & Resistant \\
\hline
\end{tabular}


Table 2. Characteristics of previously reported Bordetella hinzii infections*

\begin{tabular}{|c|c|c|c|c|c|c|}
\hline Ref.† & Type of infection & Age, y & Underlying conditions & $\begin{array}{l}\text { Animal } \\
\text { exposure }\end{array}$ & Antimicrobial drugs & $\begin{array}{c}\text { Patient } \\
\text { outcome }\end{array}$ \\
\hline (5) & Bacteremia & 24 & HIVIAIDS & None & Ceftazidime & Recovered \\
\hline (4) & Pneumonia & NA & HIVIAIDS & None & NA & NA \\
\hline (6) & $\begin{array}{l}\text { Bacteremia and } \\
\text { cholangitis }\end{array}$ & 69 & None & None & $\begin{array}{l}\text { Ticarcillin/sulbactam, } \\
\text { ciprofloxacin }\end{array}$ & Died \\
\hline (7) & Cholangitis & 29 & $\begin{array}{c}\text { Primary sclerosing cholangitis, liver } \\
\text { transplant recipient }\end{array}$ & None & Meropenem & Died \\
\hline (8) & Bacteremia & 79 & Myelodysplastic syndrome & None & Ceftazidime & Recovered \\
\hline (9) & Bacteremia & 36 & EBV associated diffuse large cell lymphoma & None & Meropenem & Died \\
\hline (10) & Pneumonia & 43 & AML, transplant, diabetes bronchiectasis & Poultry & $\begin{array}{l}\text { Piperacillin/tazobactam, } \\
\text { ciprofloxacin }\end{array}$ & Recovered \\
\hline (10) & Pneumonia & 74 & $\begin{array}{l}\text { Laryngeal cancer, prostate cancer, } \\
\text { diabetes, COPD }\end{array}$ & None & Piperacillin/tazobactam & Recovered \\
\hline (11) & $\begin{array}{l}\text { Urinary tract } \\
\text { infection }\end{array}$ & 55 & None & $\begin{array}{l}\text { Possible } \\
\text { poultry }\end{array}$ & $\begin{array}{c}\text { Trimethoprim/ } \\
\text { sulfamethoxazole }\end{array}$ & Recovered \\
\hline$(11)$ & Liver abscess & 58 & Hypothyroidism, cholecystectomy & None & None & Recovered \\
\hline (12) & $\begin{array}{l}\text { Bacteremia and } \\
\text { infective } \\
\text { endocarditis }\end{array}$ & 79 & $\begin{array}{l}\text { Aortic valve replacement, diabetes, } \\
\text { cirrhosis, colon cancer, kidney disease }\end{array}$ & None & Meropenem & Recovered \\
\hline (13) & $\begin{array}{l}\text { Bacteremia and } \\
\text { infective } \\
\text { endocarditis }\end{array}$ & 53 & Ulcerative colitis & None & Ceftazidime & Recovered \\
\hline (14) & $\begin{array}{c}\text { Soft tissue } \\
\text { abscess }\end{array}$ & 63 & None & None & Sitafloxacin & Recovered \\
\hline (15) & $\begin{array}{l}\text { Pancreatic } \\
\text { abscess }\end{array}$ & 42 & Alcoholic liver disease & None & Tigecycline & Recovered \\
\hline$(16)$ & $\begin{array}{l}\text { Urinary tract } \\
\text { infection }\end{array}$ & 37 & Chronic alcohol use & None & $\begin{array}{c}\text { Trimethoprim/ } \\
\text { sulfamethoxazole }\end{array}$ & Recovered \\
\hline$(17)$ & Pneumonia & 67 & Diabetes mellitus & None & Cefmetazole & Recovered \\
\hline
\end{tabular}

ceftazidime and ticarcillin/clavulanate. The patient we describe had received only a short course of vancomycin and cefepime before we identified B. hinzii in cultures from samples he provided. The isolate of $B$. hinzii identified had a high MIC to cefepime, 64 $\mu \mathrm{g} / \mathrm{mL}$, suggesting inadequate antimicrobial coverage before his death. This high MIC to third- and fourth-generation cephalosporins had been reported in only 1 previous case (11).

The cause of death in this case was likely multifactorial and included respiratory infection with SARS-COV-2 and the hemodynamic compromise that ensued. The role of Klebsiella isolated from BAL fluid seems unclear, but this bacterium was found only in very small quantities from the respiratory tract and was treated with appropriate antimicrobial drugs.

In summary, B. hinzii has multiple clinical manifestations and outcomes in both immunocompetent and immunocompromised patients. Reports of patients with $B$. hinzii infections seem to be increasing in recent years, which may be because of the availability of better identification methods, such as matrix-assisted laser desorption/ionization-time of flight mass spectrometry and gene sequencing, as well as an increase in the number of immunocompromised persons who have underlying conditions such as HIV, malignancy, or transplantation or who are taking immunosuppressive agents. Our patient likely had untreated lung $B$. hinzii infection that led to bacteremia. He had uncontrolled diabetes and received dexamethasone as part of his treatment, which may have resulted in dissemination through bacteremia. In addition, SARS-CoV-2 co-infection rendered him more susceptible to infection. Our findings add to the growing knowledge of emerging secondary infectious complications, including from opportunistic pathogens, concurrent with or after SARS-CoV-2 infection. The increasing case reports of invasive $B$. hinzii may indicate its emergence as a pathogen in humans.

\section{About the Author}

Dr. Maison-Fomotar is a graduating second-year infectious diseases fellow at the University of California San Francisco, Fresno, California. Her primary interests are HIV, central nervous system infections, and infectious disease issues in underserved populations.

Dr. Sivasubramanian is an assistant professor of infectious diseases at University of California San Francisco, Fresno, California. Her primary interests are fungal infections and infections in critically ill patients. 


\section{References}

1. WHO. COVID-19 dashboard [cited 2021 Jun 28]. https://covid19.who.int

2. Chen X, Liao B, Cheng L, Peng X, Xu X, Li Y, et al. The microbial coinfection in COVID-19. Appl Microbiol Biotechnol. 2020;104:7777-85. https://doi.org/10.1007/s00253-020-10814-6

3. Mattoo S, Cherry JD. Molecular pathogenesis, epidemiology, and clinical manifestations of respiratory infections due to Bordetella pertussis and other Bordetella subspecies. Clin Microbiol Rev. 2005;18:326-82. https://doi.org/10.1128/ CMR.18.2.326-382.2005

4. Gadea I, Cuenca-Estrella M, Benito N, Blanco A, FernándezGuerrero ML, Valero-Guillén PL, et al. Bordetella hinzii, a "new" opportunistic pathogen to think about. J Infect. 2000;40:298-9. https://doi.org/10.1053/jinf.2000.0646

5. Cookson BT, Vandamme P, Carlson LC, Larson AM, Sheffield JV, Kersters K, et al. Bacteremia caused by a novel Bordetella species, "B. hinzii." J Clin Microbiol. 1994;32:2569_ 71. https:// doi.org/10.1128/jcm.32.10.2569-2571.1994

6. Kattar MM, Chavez JF, Limaye AP, Rassoulian-Barrett SL, Yarfitz SL, Carlson LC, et al. Application of 16S rRNA gene sequencing to identify Bordetella hinzii as the causative agent of fatal septicemia. J Clin Microbiol. 2000;38:789-94. https:/ / doi.org/10.1128/JCM.38.2.789-794.2000

7. Arvand M, Feldhues R, Mieth M, Kraus T, Vandamme P. Chronic cholangitis caused by Bordetella hinzii in a liver transplant recipient. J Clin Microbiol. 2004;42:2335-7. https://doi.org/10.1128/JCM.42.5.2335-2337.2004

8. Fry NK, Duncan J, Edwards MT, Tilley RE, Chitnavis D, Harman R, et al. A UK clinical isolate of Bordetella hinzii from a patient with myelodysplastic syndrome. J Med Microbiol. 2007;56:1700-3. https://doi.org/10.1099/jmm.0.47482-0

9. Hristov AC, Auwaerter PG, Romagnoli M, Carroll KC. Bordetella hinzii septicemia in association with Epstein-Barr virus viremia and an Epstein-Barr virus-associated diffuse large B-cell lymphoma. Diagn Microbiol Infect Dis. 2008;61:484-6. https://doi.org/10.1016/j.diagmicrobio.2008.03.013

10. Fabre A, Dupin C, Bénézit F, Goret J, Piau C, Jouneau S, et al. Opportunistic pulmonary Bordetella hinzii infection after avian exposure. Emerg Infect Dis. 2015;21:2122-6. https:/ / doi.org/10.3201/eid2112.150400

11. Almuzara M, Barberis C, Traglia GM, Sly G, Procopio A, Vilches $\mathrm{V}$, et al. Isolation of Bordetella species from unusual infection sites. JMM Case Rep. 2015;2:e000029. https:/ / doi.org/ 10.1099/jmmcr.0.000029

12. González MM, Romano MPC, de Guzmán García Monge MT, Martín BB, García AS. Bordetella hinzii endocarditis, a clinical case not previously described. Eur J Case Rep Intern Med. 2019;6:000994.

13. Zohourian H, Sorokin AV, Ladna JM, Mushtaq F. Bordetella hinzii: an unexpected pathogen in native valve endocarditis. Can J Cardiol. 2019;35:1604.e17-9. https:/ / doi.org/10.1016/ j.cjca.2019.08.016

14. Negishi T, Matsumoto T, Shinagawa J, Kasuga E, Horiuchi K, Natori T, et al. A case of cervical subcutaneous abscess due to Bordetella hinzii. Diagn Microbiol Infect Dis. 2019;95:114865. https:/ / doi.org/10.1016/j.diagmicrobio.2019.07.003

15. Kampmeier S, Rennebaum F, Schmidt H, Riegel A, Herrmann M, Schaumburg F. Peripancreatic abscess supported by Bordetella hinzii. New Microbes New Infect. 2020;34:100650. https:// doi.org/10.1016/j.nmni.2020.100650

Address for correspondence: Geetha Sivasubramanian, Division of Infectious Diseases, Department of Internal Medicine, UCSF Fresno, 155 N Fresno St, Ste 307, Fresno, CA 93701, USA; email: geetha.sivasubramanian@ucsf.edu

\section{EID Podcast A Decade of Fatal Human Eastern Equine Encephalitis Virus Infection, Alabama}

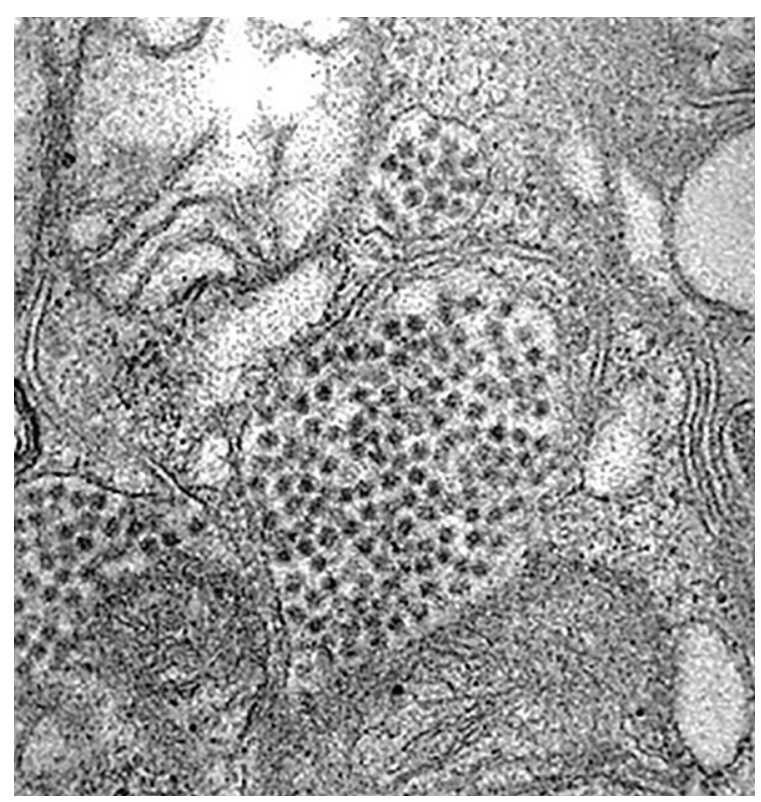

After infection with eastern equine encephalitis virus, the immune system races to clear the pathogen from the body. Because the immune response occurs so quickly, it is difficult to detect viral RNA in serum or cerebrospinal samples.

In immunocompromised patients, the immune response can be decreased or delayed, enabling the virus to continue replicating. This delay gave researchers the rare opportunity to study the genetic sequence of isolated viruses, with some surprising results.

In this EID podcast, Dr. Holly Hughes, a research microbiologist at CDC in Fort Collins, Colorado, describes a fatal case of mosquitoborne disease.

\section{Visit our website to listen: https: //go.usa.gov/xFUhU}

\section{EMERGING INFECTIOUS DISEASES}

